\title{
JEA \\ PENGARUH ASIMETRI INFORMASI DAN KETAATAN ATURAN AKUNTANSI TERHADAP KECENDERUNGAN KECURANGAN AKUNTANSI DI PEMERINTAHAN KOTA PAYAKUMBUH
}

\author{
Rifandra Adwitya ${ }^{1}$, Vita Fitria Sari ${ }^{2}$ \\ ${ }^{1}$ Alumni Jurusan Akuntansi Fakultas Ekonomi Universitas Negeri Padang \\ ${ }^{2}$ Jurusan Akuntansi Fakultas Ekonomi Universitas Negeri Padang \\ *Korespondensi: rifandraadwitiya8@gmail.com
}

\begin{abstract}
Accounting fraud occurred in the form of misstatement of financial statements, abuse of authority by rejecting information by accounting management in the government. This study aims to determine the effect of asymmetric information and compliance with accounting rules on accounting fraud in the Payakumbuh city government. The sample of 124 respondents was determined by proportional stratified random sampling consisting of direct or indirect Echelon II, III and IV accounting managers. Data were analyzed using multiple regression formulas with the help of the SPSS application for windows. This study concludes that information asymmetry and significant positive influence means increasing the likelihood of fraud. Whereas adherence to accounting rules does not affect accounting fraud due to lack of rewards and penalties for accounting managers from implementing the established rules.
\end{abstract}

Keywords: Information Asymmetry, Obedience Rules, Accounting Fraud

How to cite (APA $6^{\text {th }}$ style):

Adwitya, R., \& Sari, V.F (2020). Pengaruh Asimeri Informasi dan Ketaatan Aturan Akuntansi Terhadap Kecenderungan Kecurangan Akuntansi di Pemerintah Kota Payakumbuh. Jurnal Eksplorasi Akuntansi, 2(1), Seri E, 2526-2536.

\section{PENDAHULUAN}

Perkembangan akuntansi, dapat memberikan masalah. Masalah yang terjadi adalah kecenderungan melakukan kecurangan akuntansi. Di sektor publik, kecurangan akuntansi cenderung terjadi dalam kebocoran anggaran pendapatan belanja negara (APBN), sementara kecurangan akuntansi sektor swasta cenderung terjadi dalam bentuk yang hampir sama, yaitu ketidaktepatan pengeluaran belanja modal (Thoyibatun, 2009). Kecenderungan kecurangan akuntansi dapat membahayakan institusi yang dikelola. Kecenderungan adalah keinginan, kecenderungan, atau kebahagiaan hati untuk melakukan sesuatu atau melakukan penipuan karena peluang. Kecenderungan kecurangan akuntansi dapat disebut kecenderungan untuk melakukan korupsi dalam definisi dan terminologi karena keterlibatan beberapa elemen seperti pengungkapan fakta menyesatkan, pelanggaran aturan dan penyalahgunaan kepercayaan (Ariani et al, 2015). 
Kecurangan akuntansi atau dalam bahasa audit, sering disebut sebagai fraud. Pada dasarnya, dalam sebuah perusahaan ada dua jenis penipuan, yaitu eksternal dan internal. Penipuan eksternal adalah penipuan di luar agensi atau perusahaan, dan penipuan internal adalah tindakan ilegal karyawan, manajemen, dan eksekutif terhadap agensi dan perusahaan (Amin Widjaja, 2013). Kecenderungan kecurangan akuntansi adalah salah satu faktor utama yang menyebabkan korupsi. Penipuan adalah tindakan melanggar hukum dan melanggar hukum dari seorang pejabat atau karyawan dengan menggunakan pekerjaan dan lokasinya sebagai alat untuk mendapatkan keuntungan pribadi atau lainnya dengan mengambil hak-hak orang lain (Hall Singleton, 2007). Di Indonesia, penanganan korupsi setiap tahun mencapai 1.600 hingga 1.700 kasus, yang menjadikan Indonesia berada di peringkat kedua setelah China menjadi 4.500 kasus (www.bisnis-jateng.com).

Faktor pertama yang mempengaruhi kecenderungan kecurangan akuntansi adalah inkonsistenan informasi(asimetri Informasi). Nicholson (1997) mencatat dalam Kusumastuti (2012) bahwa tindakan yang diambil oleh manajemen dipengaruhi oleh asimetri informasi. Menurut Wilopo (2006), asimetri informasi adalah situasi di mana informasi tidak selaras antara mereka yang memberikan dan mereka yang membutuhkan informasi. Asimetri informasi ini dapat menyebabkan kecurangan akuntansi antara pemerintah daerah dan parlemen daerah dengan perbedaan informasi atau ketidakkonsistenan dalam persiapan anggaran yang mengakibatkan anggaran belanja modal di OPD menjadi tidak tepat.

Faktor kedua yang dapat mempengaruhi kecenderungan kecurangan akuntansi adalah ketaatan aturan akuntansi. Aturan adalah tindakan yang harus dilaksanakan dan tidak dilanggar (Rahmawati, 2012). Instansi atau lembaga pemerintah akan melakukan kecurangan akuntansi jika tidak mengikuti aturan yang ditetapkan karena tidak mengacu pada aturan akuntansi yang berlaku. Mematuhi aturan akuntansi adalah kewajiban organisasi karena jika laporan keuangan disusun dengan cara yang tidak sesuai atau tidak mengikuti aturan akuntansi yang ditetapkan, ini dapat menyebabkan perilaku tidak bermoral dan menyebabkan kecurangan akuntansi (Prekanida, 2015).

Operasi Tangkap Tangan oleh Komisi Pemberantasan Korupsi (KPK) terhadap dua auditor Badan Pemeriksa Keuangan (BPK) juga mendapat berbagai tanggapan dari sejumlah pihak di Sumatera Barat. Termasuk mempertanyakan pendapat WTP yang baru saja diterima oleh Pemerintah Provinsi Sumatera Barat. OTT berkaitan dengan pemberian gelar "Wajar tanpa Pengecualian" (WTP) kepada Kementerian Desa, Pengembangan Daerah Tertinggal dan Imigrasi Transit (Kemendes PDTT). Alasannya adalah bahwa Sumatera Barat mendapat WTP di tengah dugaan penyimpangan 30 elemen dalam laporan keuangan pemerintah daerah (LKPD) 2016, dengan hasil mencapai 45 miliar rupiah.

Seorang ahli hukum konstitusi dari Universitas Andalusia, Phiri Amsari mengatakan bahwa para penyandang cacat yang diperoleh oleh pemerintah provinsi Sumatera Barat adalah tersangka. Keraguan tentang Orang-Orang yang Terkena Dampak Proyek yang diperoleh oleh pemerintah provinsi Sumatera Barat didasarkan pada kecurigaan bahwa sekitar Rp. 45 miliar dana menyimpang dari 30 artikel yang ditemukan dalam LKPD. Ini adalah indikasi keliru dari situasi para penyandang cacat yang diterima oleh Pemerintah Provinsi Sumatera Barat. Dia memperkuat pandangannya dengan mengatakan bahwa WTP hanya hasil audit. Hasil audit BPK mungkin salah, termasuk hasil audit BPKP di Kabupaten Payakumbuh (Harianhaluan.com).

Penelitian ini didasarkan pada penelitian sebelumnya oleh Devy Ervina Indriastuti et al. (2016) Perbedaan dalam penelitian ini dengan penelitian sebelumnya terletak pada subjek penelitian dan waktu yang berbeda. Dalam mempelajari Devy Ervina Indriastuti et al. (2016) 
bertujuan untuk meneliti pada pemerintah pusat Kabupaten Lombok. Sementara penelitian ini bertujuan untuk meneliti semua OPD di Payakumbuh, penelitian sebelumnya hanya memilih satu OPD di Kabupaten Lombok, sementara penelitian ini mengambil sampel dari semua OPD di Payakumbuh.

\section{REVIU LITERATUR DAN PENGEMBANGAN HIPOTESIS Teori Fraud Diamond}

Teori Fraud Diamond dikemukakan oleh Wolfe dan Hermanson (2004) dengan menambahkan tiga faktor penyebab terjadinyan kecurangan akuntansi yang ditemukan Cressey (1953) yaitu tekanan (pressure), kesempatan (opportunity), dan rasionalisasi (rationalization) dengan faktor kemampuan (capability).

\section{Kecenderungan Kecurangan Akuntansi}

Kecenderungan kecurangan akuntansi menurut Shintadevi (2015) adalah keinginan untuk melakukan segalanya untuk keuntungan yang tidak adil, penipuan, liputan fakta, manipulasi dan penipuan dalam bentuk kesalahan data keuangan, korupsi dan penyalahgunaan aset.

\section{Asimetri Informasi}

Wilopo (2006) di Saftarini et al. (2015) Ketidakkonsistenan informasi memberikan situasi di mana informasi tidak selaras antara pihak-pihak yang memiliki atau memberikan informasi dengan mereka yang membutuhkan informasi. Adanya asimetri informasi dalam entitas akan menyebabkan pihak internal mendapat manfaat dari asimetri informasi untuk pengambilan keuntungan dan dapat membahayakan pihak eksternal entitas.

\section{Ketaatan Aturan Akuntansi}

Menurut Prekanida (2015), kepatuhan adalah posisi individu terhadap aturan atau perintah, sedangkan aturan adalah metode atau prosedur yang telah ditentukan yang harus dijalankan atau dipatuhi. Di salah satu lembaga, ada dasar atau pedoman yang digunakan manajemen untuk mendefinisikan dan mengimplementasikan berbagai kegiatan dalam perusahaan, salah satunya adalah aturan yang terkait dengan kegiatan akuntansi.

\section{Pengaruh Asimetri Informasi terhadap Kecenderungan Kecurangan Akuntansi}

Menurut Najahningrum (2013) pada Saftarini et al. (2015) Ketidakkonsistenan Informasi adalah situasi di mana pihak-pihak dalam suatu perusahaan mengetahui informasi lebih baik daripada pihak-pihak di luar perusahaan. Jika ada kesenjangan informasi antara pengguna dan manajer, itu akan membuka peluang bagi manajer dana untuk melakukan penipuan. Ketidakkonsistenan informasi terjadi ketika lembaga internal hanya mengetahui isi aktual dan jumlah laporan keuangan yang disiapkan (Najahningrum, 2013). Kesenjangan informasi antara manajer dan pengguna terkait dengan persiapan laporan keuangan entitas publik. Ini karena tidak ada transparansi atau keterbukaan antara manajemen keuangan dan publik untuk mendapatkan informasi ini.

Hubungan antara prinsipal dan agen, menurut teori agensi, mengarah pada keadaan informasi asimetris karena agen berada dalam posisi yang mengandung lebih banyak informasi tentang perusahaan daripada prinsipal. Dengan asumsi bahwa individu bertindak untuk memaksimalkan kepentingan mereka sendiri, asimetri informasi yang mereka miliki akan mendorong agen untuk menyembunyikan beberapa informasi yang tidak diketahui prinsipal. 
Dalam hal ini, agen dapat mempengaruhi angka akuntansi yang disajikan dalam laporan keuangan dengan memanipulasi (Setiawan et al., 2015).

Ketidakkonsistenan informasi adalah cacat pada informasi yang dimiliki oleh manajer dan agen, ketika direktur tidak memiliki informasi yang cukup tentang kinerja agen, sebaliknya, agen memiliki lebih banyak informasi tentang kemampuan jiwa, lingkungan kerja dan perusahaan secara keseluruhan (Ariani et al., 2015). Ini membuat manajemen (agen) berpikir tentang mengubah angka akuntansi sehingga mereka dapat digunakan untuk meningkatkan minat mereka. Pendapat ini didukung oleh penelitian sebelumnya dan Ariani et al. (2015) dan SListini et al. (2015) yang menyatakan bahwa ada pengaruh antara inkonsistensi informasi dan kecenderungan kecurangan akuntansi untuk menyiratkan bahwa semakin besar inkonsistensi informasi yang dimiliki organisasi, semakin besar kecenderungan kecurangan akuntansi untuk meningkat juga.

H1: Asimetri informasi berpengaruh positif terhadap kecenderungan kecurangan akuntansi.

\section{Pengaruh Ketaatan Aturan Akuntansi terhadap Kecenderungan Kecurangan Akuntansi}

Thoyibatun (2009) menjelaskan bahwa kepatuhan dengan aturan akuntansi dipandang sebagai tingkat kesesuaian prosedur manajemen aset organisasi, penerapan prosedur akuntansi, dan penyajian laporan keuangan bersama dengan semua bukti pendukung, dengan aturan yang ditetapkan oleh BPK atau SAP. Sementara Wilopo (2006) menjelaskan bahwa penyusunan laporan keuangan dikatakan gagal karena ketidakpatuhan terhadap aturan akuntansi, karena ini akan mengarah pada kecurangan akuntansi yang tidak dapat dideteksi atau di monitor.

Aturan akuntansi dapat mencegah dan mengurangi kecurangan akuntansi, yang berarti bahwa semakin taat aturan akuntansi, semakin rendah kecenderungan untuk melakukan kecurangan dalam agen tersebut. Pandangan ini didukung oleh penelitian sebelumnya oleh Wilopo (2006) dan Thoyibatun (2009), dan berdasarkan uraian di atas, hipotesis dalam penelitian ini adalah:

H2: Ketaatan aturan akuntansi berpengaruh negatif terhadap kecenderungan kecurangan akuntansi

\section{Kerangka Konseptual}

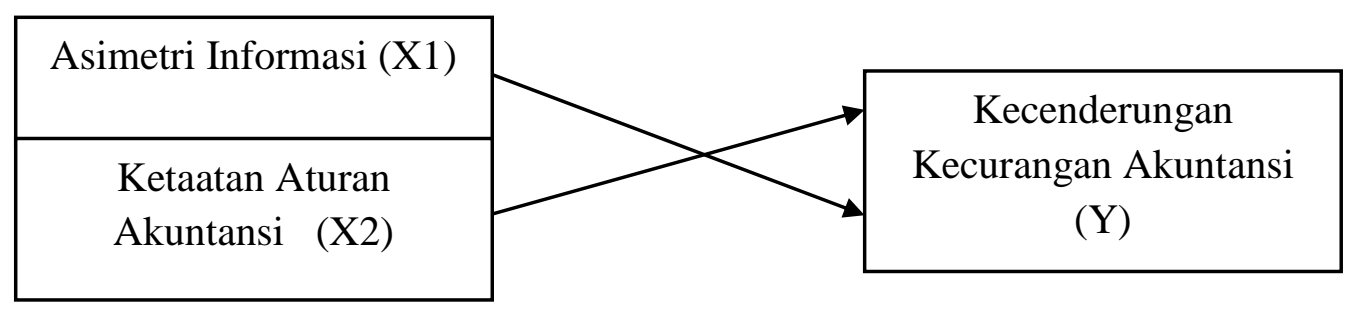

\section{Gambar 1. Kerangka Konseptual}

\section{METODE PENELITIAN}

\section{Desain Penelitian}

Jenis penelitian ini adalah deskriptif kausatif yang merupakan penelitian yang bertujuan untuk mengetahui ada atau tidak nya hubungan sebab akibat antara dua variabel atau lebih. 


\section{Populasi, Sampel, dan teknik pengambilan Sampel}

Populasi pada penelitian ini adalah 31 OPD Kota Payakumbuh yang terdiri dari Dinas, Badan, Sekretariat dan Inspektorat. Sampel dalam penelitian adalah sebagian yang diambil dari populasi yang akan diselidiki. Dalam penelitian ini peneliti menggunakan teknik pengambilan Total Sampling, yakni menjadikan seluruh populasi sebagai sampel karena penelitian ini kurang dari 100 subjek. Jadi, sampel penelitian ini adalah seluruh Organisasi Perangkat Daerah (OPD) Kota Payakumbuh. Adapun kriteria responden yang telah tentukan oleh peneliti dalam penelitian ini adalah kepala bidang atau kepala bagian OPD dan 3 staf atau karyawan bagian keuangan dan akuntansi.

\section{Jenis dan Sumber Data}

Jenis data dalam penelitian ini adalah data subjek. Menurut Sugiyono (2010), "data subjek adalah jenis data penelitian yang berupa opini, sikap, pengalaman atau karakteristik dari seseorang atau sekelompok orang yang menjadi objek penelitian (responden)". Data berupa tanggapan penulis atas pertanyaan atau kuesioner dari subjek penelitian pada OPD Kota Payakumbuh.

Sumber data dalam penelitian ini adalah data primer. Menurut Sugiyono (2013) data primer adalah sumber data yang langsung memberikan data kepada pengumpul data.Data primer dalam penelitian ini adalah data yang diperoleh dengan menyebarkan kuesioner kepada responden yang menduduki jabatan di bidang yang berkaitan dengan anggaran pada OPD Kota Payakumbuh.

\section{Teknik Pengumpulan Data}

Teknik Pengumpulan data yang dilakukan dalam penelitian ini menggunakan kuesioner dengan cara membagi angket kuesioner yang berisi pertanyaan yang sudah disiapkan alternatif jawabannya.

\section{HASIL DAN PEMBAHASAN Uji Asumsi Klasik Uji Normalitas}

Uji normalitas digunakan untuk menguji apakah distribusi data mengikuti atau mendekati distribusi normal. Data yang baik adalah data yang pola distribusinya normal. Uji normalitas dapat dilakukan dengan metode Kolmogorav-Smirnov test. Hasil pengolahan SPSS Versi 21 didapat bahwa hasil uji normalitas menunjukkan level signifikan lebih kecil dari $\alpha(\alpha=$ 0,05 ) yaitu $0,839>0,05$ sehingga data tidak terdistribusi secara normal seperti tabel dibawah ini: 


\section{Tabel 1}

One-Sample Kolmogorov-Smirnov Test

\begin{tabular}{|ll|l|}
\hline & & $\begin{array}{l}\text { Unstandardized } \\
\text { Residual }\end{array}$ \\
\hline $\mathrm{N}$ & & 124 \\
Normal & Mean & .0000000 \\
Parameters ${ }^{\mathrm{a}, \mathrm{b}}$ & Std. & 2.75620043 \\
& Deviation & .056 \\
Most & Absolute & .056 \\
Extreme & Positive & .032 \\
Differences & Negative & -.056 \\
Kolmogorov-Smirnov Z & .618 \\
Asymp. Sig. (2-tailed) & .839 \\
\hline
\end{tabular}

a.Test distribution is Normal.

b. Calculated from data.

Sumber:Data primer yang diolah tahun2020

Uji Multikolenearitas

Tabel 2

\begin{tabular}{|c|c|c|c|}
\hline \multirow{2}{*}{\multicolumn{2}{|c|}{}} & \multicolumn{2}{|c|}{ Collinearity Statistics } \\
\cline { 3 - 4 } Model & Tolerance & VIF \\
\hline \multirow{2}{*}{ (Constant) } & X1 &, 991 & 1,010 \\
\cline { 2 - 4 } & X2 &, 991 & 1,010 \\
\hline
\end{tabular}

Sumber: Data primer yang diolah tahun 2020

Berdasarkan tabel di atas, dapat diketahui bahwa variabel asimetri informasi dengan nilai (VIF) dengan nilai 1,010 dan toleransi 0,991, dan variabel kepatuhan untuk aturan akuntansi dengan nilai (VIF) 1,010 dengan toleransi 0,991. Dengan demikian dapat dikatakan bahwa tidak ada korelasi antara variabel independen satu sama lain, atau bahwa variabel independen dalam penelitian ini bebas dari gejala linier berganda.

\section{Uji Heteroskedastisitas}

Tabel 3

\begin{tabular}{|c|c|c|c|c|c|c|c|}
\hline \multirow[b]{2}{*}{ Model } & \multicolumn{2}{|c|}{$\begin{array}{l}\text { Unstandardized } \\
\text { Coefficients }\end{array}$} & \multirow{2}{*}{$\begin{array}{c}\begin{array}{c}\text { Standardized } \\
\text { Coefficients }\end{array} \\
\text { Beta }\end{array}$} & \multirow[b]{2}{*}{$\mathrm{t}$} & \multirow[b]{2}{*}{ Sig. } & \multicolumn{2}{|c|}{ Collinearity Statistics } \\
\hline & $\mathrm{B}$ & Std. Error & & & & Tolerance & VIF \\
\hline 1 (Constant) & 2.226 & 1.644 & & 1.354 & .178 & & \\
\hline $\mathrm{x} 1$ & .047 & .029 & .145 & 1.607 & .111 & .991 & 1.010 \\
\hline $\mathrm{x} 2$ & -.028 & .045 & -.056 & -.619 & .537 & .991 & 1.010 \\
\hline
\end{tabular}

a. Dependent Variable: ABS_res2

Sumber:Data Primer yang diolah, 2020 
Tabel di atas menunjukkan bahwa nilai pentingnya variabel inkonsistensi informasi dan kepatuhan terhadap aturan akuntansi memiliki nilai lebih besar dari nilai $=0,05$. Ini menunjukkan bahwa penelitian ini lulus uji heteroskedastisitas.

\section{Uji Hipotesis}

Analisis Regresi Berganda

Tabel 4

\begin{tabular}{|c|c|c|c|c|c|}
\hline \multirow[b]{2}{*}{ Model } & \multicolumn{2}{|c|}{$\begin{array}{l}\text { Unstandardized } \\
\text { Coefficients }\end{array}$} & \multirow{2}{*}{$\begin{array}{c}\text { Standardized } \\
\text { Coefficients } \\
\text { Beta } \\
\end{array}$} & \multirow[b]{2}{*}{$\mathrm{t}$} & \multirow[b]{2}{*}{ Sig. } \\
\hline & $\mathrm{B}$ & $\begin{array}{l}\text { Std. } \\
\text { Error }\end{array}$ & & & \\
\hline $1 \quad$ (Constant) & 12.193 & 2.601 & & 4.687 & .000 \\
\hline $\mathrm{x} 1$ & .098 & .046 & .186 & 2.138 & .035 \\
\hline $\mathrm{x} 2$ & .186 & .072 & .225 & 2.585 & .011 \\
\hline
\end{tabular}

a. Dependent Variable: Y

Sumber: Data primer yang diolah 2020

Berdasarkan tabel 4.14 di atas dapat dianalisis model persamaan sebagai berikut:

Keterangan:

$$
\mathrm{Y}=12,193+0.098 \times 1+0,186 \times 2+e
$$

$\mathrm{Y} \quad=$ Kecenderungan Kecurangan Akuntansi

$\mathrm{X} 1=$ Asimetri Informasi

$\mathrm{X} 2=$ Ketaatan Aturan Akuntansi

\section{Uji Kelayakan Modal}

\section{Koefisien Determinasi R2}

Tabel 5

Model Summary ${ }^{\mathrm{b}}$

\begin{tabular}{|l|c|r|r|c|}
\hline Model & R & R Square & $\begin{array}{c}\text { Adjusted } \\
\text { R Square }\end{array}$ & $\begin{array}{c}\text { Error of } \\
\text { the } \\
\text { Estimate }\end{array}$ \\
\hline 1 &, $305^{\mathrm{a}}$ & .093 & .078 & 2.77889 \\
\hline
\end{tabular}

a. Predictors: (Constant), $\mathrm{x} 1, \mathrm{x} 2$

b. Dependent Variable: y

Sumber: Data primer yang diolah, 2020

Berdasarkan tabel di atas besarnya Adjusted $R$ Square adalah 0,078. Hal ini mengidentifikasikan bahwa kontribusi variabel independen terhadap variabel dependen adalah sebesar 7,8 \%, sedangkan $92,2 \%$ lainnya ditentukan oleh faktor lain diluar model yang tidak terdeteksi dalam penelitian ini. 


\section{Uji F}

Tabel 6

ANOVA $^{\mathrm{a}}$

\begin{tabular}{|cc|c|c|c|c|c|}
\hline \multicolumn{1}{|c|}{ Model } & $\begin{array}{c}\text { Sum of } \\
\text { Squares }\end{array}$ & Df & $\begin{array}{c}\text { Mean } \\
\text { Square }\end{array}$ & F & Sig. \\
\hline 1 & Regression & 96.097 & 2 & 48.049 & 6.222 &, $003^{\mathrm{b}}$ \\
& Residual & 934.387 & 121 & 7.722 & & \\
Total & 1030.484 & 123 & & & \\
\hline
\end{tabular}

a. Dependent Variable: y

b. Predictors: (Constant), x1, x2

Sumber: Data yang diolah, 2020

Hasil pengolahan statistik analisis regresi menunjukkan nilai $\mathrm{F}=6,222$ dan signifikansi pada level 0,003. Jadi Fhitung > Ftabel yaitu 6,222>3,07 (sig. 0,003<0,05). Hal ini menunjukkan bahwa model regresi dapat digunakan untuk menguji pengaruh variabel independen terhadap variabel dependen.

\section{Uji Hipotesis (t-test)}

Tabel. 6

\begin{tabular}{|c|c|c|c|c|c|}
\hline \multirow[b]{2}{*}{ Model } & \multicolumn{2}{|c|}{$\begin{array}{l}\text { Unstandardized } \\
\text { Coefficients }\end{array}$} & \multirow{2}{*}{$\begin{array}{c}\begin{array}{c}\text { Standardized } \\
\text { Coefficients }\end{array} \\
\text { Beta }\end{array}$} & \multirow[b]{2}{*}{$\mathrm{T}$} & \multirow[b]{2}{*}{ Siq. } \\
\hline & B & Std. Error & & & \\
\hline 1 (Constant) & 12.193 & 2.601 & & 4.687 & .000 \\
\hline $\mathrm{x} 1$ & .098 & .046 & .186 & 2.138 & .035 \\
\hline $\mathrm{x} 2$ & .186 & .072 & .225 & 2.585 & .011 \\
\hline
\end{tabular}

a. Dependent Variable: Y

Sumber:Data Primer yang diolah 2020

Berdasarkan hasil analisis pada tabel ini maka dapat diketahui pengaruh variabel independen secara parsial terhadap variabel dependen adalah sebagai berikut.

\section{Pengaruh Asimetri Informasi Terhadap Kecenderungan Kecurangan Akuntansi}

Hasil penelitian menunjukkan bahwa variabel asimetri informasi memiliki dampak positif yang signifikan terhadap kecenderungan kecurangan akuntansi. Hal ini ditunjukkan oleh koefisien regresi x1 yaitu 0,098 dengan nilai signifikansi 0,035 yang lebih kecil dari 0,05, yang menunjukkan bahwa variabel asimetri informasi memiliki hubungan langsung dengan kecenderungan kecurangan akuntansi.

Ini menjelaskan bahwa lembaga dengan tingkat asimetri informasi yang tinggi akan mempengaruhi arah kecurangan akuntansi, karena hasil penelitian ini didukung oleh penelitian sebelumnya yang dilakukan oleh Wilopo (2006), yang memperoleh hasil bahwa dengan asimetri informasi yang tinggi akan meningkatkan kecenderungan kecurangan dalam Akuntansi. Penelitian ini juga sejalan dengan penelitian Devy Ervina Indriastuti (2016), yang menyatakan 
bahwa semakin banyak informasi yang tidak simetris meningkatkan peluang terjadinya kecurangan akuntansi.

\section{Pengaruh Ketaatan Aturan Akuntansi Terhadap Kecenderungan Kecurangan Akuntansi}

Berdasarkan hipotesis kedua, ini menunjukkan bahwa kepatuhan terhadap aturan akuntansi tidak secara negatif mempengaruhi kecenderungan penipuan akuntansi. Hal ini ditunjukkan oleh koefisien regresi x 2 yang bernilai 0,186 dengan tren positif dengan nilai 0,011 kurang dari 0,05. Ini menunjukkan bahwa kepatuhan terhadap peraturan akuntansi tidak berpengaruh signifikan terhadap kecenderungan kecurangan akuntansi. Dengan demikian hipotesis kedua (H2) ditolak. Dapat disimpulkan bahwa kepatuhan yang tinggi terhadap aturan akuntansi tidak mampu mengurangi kecenderungan kecurangan akuntansi. Ketaatan pada aturan akuntansi dapat mengurangi kecenderungan kecurangan akuntansi jika disertai dengan pengendalian internal dan moral yang baik dari karyawan itu sendiri, sehingga tidak ada niat atau peluang yang memberi karyawan kesempatan untuk melakukan kecurangan akuntansi.

Temuan ini konsisten dengan temuan penelitian oleh Alief (2015) yang menyatakan bahwa kepatuhan terhadap aturan akuntansi tidak mempengaruhi kecenderungan kecurangan akuntansi. Temuan ini juga sejalan dengan penelitian oleh Kusumastuti (2012) yang menyatakan bahwa kepatuhan terhadap peraturan akuntansi tidak memiliki banyak dampak pada kecenderungan kecurangan akuntansi.

\section{Kesimpulan, Keterbatasan dan Saran \\ Kesimpulan}

Penelitian ini bertujuan untuk melihat apakah asimetri informasi dan ketaatan aturan akuntansi berpengaruh terhadap kecenderungan kecurangan akuntansi studi empiris pada seluruh OPD Kota Payakumbuh. Berdasarkan hasil penelitian dan pengujian hipotesis yang telah dilaksanakan, maka hasil penelitian dapat disimpulkan bahwa: Hipotesis pertama ketaatan aturan akuntansi tidak berpengaruh terhadap kecenderungan kecurangan akuntansi. Hasil pengujian menunjukkan bahwa ketaatan aturan akuntansi tidak memiliki pengaruh signifikan terhadap kecenderungan kecurangan akuntansi di Kota Payakumbuh. Hipotesis kedua asimetri informasi berpengaruh positif terhadap kecenderungan kecurangan akuntansi di Kota Payakumbuh. Dimana semakin tinggi tingkat asimetri informasi atau kesenjangan informasi antara pembuat laporan keuangan dengan pengguna laporan keuangan, maka akan meningkatkan tingkat kecenderungan kecurangan akuntansi.

\section{Keterbatasan}

Objek pencarian terbatas hanya untuk OPD di Payakumbuh sehingga hasil pencarian belum dapat digeneralisasi untuk semua objek secara keseluruhan. Model penelitian yang digunakan, diketahui bahwa variabel pencarian yang digunakan hanya dapat menjelaskan 7,8\%, sedangkan sisanya 92,2\% dijelaskan oleh faktor lain yang tidak diteliti dalam penelitian ini. Akibatnya, variabel penelitian yang digunakan tidak dapat menjelaskan dampak tren kecurangan akuntansi.

\section{Saran}

Penelitian selanjutnya untuk dapat memperluas ruang lingkup pengguna informasi keuangan, tidak hanya ke OPD di wilayah Kota Payakumbuh, tetapi juga dapat mencakup wilayah lain. Cari variabel untuk menemukan variabel lain yang lebih kuat mempengaruhi kecenderungan kecurangan akuntansi. 


\section{DAFTAR PUSTAKA}

Adelin, Vani dan Eka, F. (2013). Pengaruh Pengendalian Internal, Ketaatan pada Aturan Akuntansi dan Kecenderungan Kecurangan Terhadap Perilaku Tidak Etis. E-Jurnal Akuntansi Universitas Negeri Padang, 1(2).

Amalia, R. D. (2015). Pengaruh keefektifan pengendalian internal, kesesuaiankompensasi, moralitas aparat dan asimetri informasi terhadap kecenderungan kecurangan akuntansi (Studi empiris pada Pemerintah Daerah Kabupaten Siak Sri Indrapura). JOM

FEKON, 2 (2).

Amin W. T (2013). Pengendalian Internal ; Mencegah dan Mendeteksi Kecurangan, Harvarindo, Jakarta.

Ariani, K. S., Herawati, N. T., \& Ganesha, U. P. (2015). Analisis Pengaruh Moralitas Individu, Asimetri Informasi dan Keefektifan Sistem Pengendalian Internal terhadap Kecenderungan Kecurangan Akuntansi di PDAM Kabupaten Bangli. E-Journal S1 Ak Universitas Pendidikan Ganesha, 2.

Baxevani, M., \& Mylonas, G. (2014). Accounting Fraud and Characteristics of Company Executives : an Empirical Investigation, Scientific Bulletin-Economic Sciences, 13(2).

Black, J., Nilsson, M., Pinheiro, R., \& Silva, M. (2015). Information Production and the Duration of Accounting Fraud, Working Papers Federal Reserve Bank of Cleveland $1-61$.

Chui, L and Byron, Pike. (2013). Auditors' responsibility for fraud detection: New wine in old bottles?. Journal of Forensic \& Investigative Accounting 5,(1), January-June..

Ghozali, I. 2005. Aplikasi Analisis Multivariate dengan Program SPSS. Semarang : Badan Penerbit Universitas Diponegoro.

Ghozali, I. 2011. Aplikasi Analisis Multivariate dengan Program IBM SPSS.Semarang: Universitas Diponegoro.

Hall, J ,A ,T S . (2007). Audit Teknologi dan Assurance (edisi 2). Jakarta,Indonesia: Salemba Empat.

Ikatan Akuntan Indonesia. (2009). Standar Akuntansi Keuangan. Jakarta: IkatanAkuntan Indonesia.

Indriastuti, D. E. dan Agusdindan A. (2016). Analisis Pengaruh Asimetri Informasi, Pengendalian Internal,Persepsi Kesesuaian Kompensasi, Moralitas Individu, Dan KetaatanAturan Akuntansi Terhadap Kecurangan Akuntansi. Jurnal In Festai 12 (2), 115 -130 .

Kusumastuti, W, (2012). Analisis Faktor-Faktor Yang Berpengaruh Terhadap Kecenderungan Kecurangan Akuntansi Dengan Perilaku Tidak Etis Sebagai Variabel Intervening. Diponegoro journal of acccounting volume, 1(2)

Mark F. Z, Conan C. Albrecht, W. And Steve , C. O. A.( 2014). Akuntansi Forensik. Jakrta. Penerbit: Salemba Empat.

Mia A, S dan Helmayunita, N. (2017). Pengaruh pengendalian internal, tekanan finansial, dan moralitas individu terhadap kecenderungan kecurangan akuntansi: studi eksperimen pada konteks pemerintahan daerah. Economac journal, 1(1).

Najahningrum, A, F. (2013). Faktor-faktor yang Mempengaruhi Kecenderungan Kecurangan (Fraud): Persepsi Pegawai Dinas Provinsi DIY. Skripsi. Universitas Negeri Semarang.

Omposungu, K.B., \& I.R, Banowo. (2007). Pengaruh Partisipasi Anggaran dan Job Relevan Information (JRI) terhadap Asimetri Informasi. Jurnal Akuntansi dan Keuangan Sektor Publik, 8(1). 
Rahmawati, A, P. 2012. Analisis Pengaruh Faktor Internal dan Moralitas Manajemen terhadap Kecenderungan Kecurangan Akuntansi Studi Pada Dinas Pengelola Keuangan dan Aset Daerah Kota Semarang. Tesis. Semarang: Universitas Diponergoro.

Saftarini, R. P, Yuniarta, A. G. \& Sinawarti, K. Ni. (2015). Pengaruh Efektivitas Pengendalian Internal, Asimetri Informasi Dan Implementasi Good Governance Terhadap Kecenderungan Kecurangan (Fraud) Akuntansi. Program Akuntansi Universitas Pendidikan Ganesha. Singaraja. e-Journal S1 Akuntansi Universitas Pendidikan Ganesha, 3(1). 